\title{
DINAMIKA PENGGUNAAN/TUTUPAN LAHAN DAN KESELARASANNYA DENGAN POLA RUANG DAN DAYA DUKUNG LAHAN: STUDI KASUS DI KECAMATAN CIATER, KABUPATEN SUBANG, PROVINSI JAWA BARAT
}

\author{
Dinamics of Land Use/Cover and Its Conformity with Spatial Plan, and Land \\ Carrying Capacity: Case Study in Ciater Sub District, Subang Regency, West \\ Java Province
}

\author{
Setyardi Pratika Mulya 1)*, Deni Suherlan²) dan Andrea Emma Pravitasari 1) \\ 1) Departemen Ilmu Tanah dan Sumberdaya Lahan, Fakultas Pertanian IPB University, Jl. Meranti \\ Kampus IPB Darmaga Bogor 16680 \\ 2) Program Studi Manajemen Sumberdaya Lahan, Departemen Ilmu Tanah dan Sumberdaya Lahan, \\ Fakultas Pertanian IPB University, Jl. Meranti Kampus IPB Darmaga Bogor 16680
}

\begin{abstract}
Ciater Sub-District is included in the southern part of Subang District which has a strategic function as a water catchment area, including natural reserves, nature tourism park and production forest. This condition needs to be controlled appropriately and sustainable. It should be noted that natural resource management for economic purposes sometimes ignores environmental factors. Therefore, there is a need for continuity between land use with spatial patterns and land carrying capacity (land capability), so there is no damage/disaster. This study aims to determine the types of land use/cover in 2006 and 2019 and their changes, to evaluate conformity of land use 2019 with spatial planning Subang District 2011-2031, and the carrying capacity of the land as well as the land value zone information on each combination of conformity. The basic methods used included geographic information systems (visual delineation, overlays, queries) and logical conformity matrices and land capability analysis by collecting data from field observations. The results showed that the most extensive land use/cover in each year was secondary forest with medium density with a percentage of 22.72\% (2006), and 18.85\% (2019). The most extensive pattern of change was from secondary forests of moderate density in 2006 to mixed gardens in 2019 with an percent area of $25.25 \%$ (173.35 ha). Land capability classes II, III and IV in Ciater District are 79.89\%, while land capability classes VI are $20.11 \%$. The analysis shows that the percent area of $57.25 \%$ conformed, $20.44 \%$ is not-conformed, while $22.30 \%$ is a transition. Thus, land in the study area is still relatively good in terms of conformity between the land carrying capacity with the existing policy. However, the occurrence of disasters at certain location points needs to get attention for all parties to be mitigated. Other results show, land conformity does not depend on land value, because on land that is conform (S) and not conform (TS), both have low land values. In land use planning, ecological and economic aspects are important aspects that need attention.
\end{abstract}

Keyword: conformity, land capability, land value, spatial planning

\section{ABSTRAK}

Kecamatan Ciater termasuk wilayah Kabupaten Subang bagian selatan yang memiliki fungsi strategis sebagai kawasan resapan air, yang didalamnya melingkupi cagar alam, taman wisata alam serta sebagian wilayahnya merupakan hutan produksi. Kondisi ini perlu dikendalikan pemanfaatannya secara tepat dan berkelanjutan. Pemanfaatan sumberdaya alam untuk kepentingan ekonomi terkadang mengabaikan faktor lingkungan. Oleh karena itu, perlu adanya keselarasan antara penggunaan lahan, kebijakan (pola ruang), dan daya dukung lahannya (kemampuan lahan), agar tidak terjadi kerusakan/bencana. Penelitian ini bertujuan mengetahui jenis-jenis tutupan/penggunaan lahan tahun 2006 dan 2019 serta perubahannya, mengevaluasi keselarasan penggunaan lahan 2019 dengan pola ruang RTRW Kabupaten Subang 2011-2031 dan daya dukung lahannya serta informasi zona nilai tanah pada setiap kombinasi keselarasan. Metode dasar yang digunakan antara lain sistem informasi geografi (deliniasi visual, overlay, query), dan matriks logis keselarasan serta analisis kemampuan lahan dengan pengumpulan data dari pengamatan lapang, Hasil penelitian menunjukkan tutupan/penggunaan lahan terluas di masing-masing tahun adalah hutan sekunder kerapatan sedang dengan persentase $22.72 \%$ pada tahun 2006 dan $18.85 \%$ pada tahun 2019. Perubahan penggunaan lahan yang paling luas adalah dari hutan sekunder kerapatan sedang pada tahun 2006 berubah menjadi kebun campuran pada tahun 2019 dengan persentase luas $25.25 \%$ (173.35 ha). Kelas kemampuan lahan II, III dan IV di Kecamatan Ciater persentase cakupan luasnya $79.89 \%$, sedangkan kelas kemampuan lahan VI seluas $20.11 \%$. Hasil analisis menunjukkan persentase keselarasan $57.25 \%$ selaras, $20.44 \%$ tidak selaras, dan $22.30 \%$ transisi. Dengan demikian, lahan di wilayah studi relatif masih baik dalam hal keselarasan antara daya dukung lahannya dengan kebijakan yang ada. Namun demikian, adanya bencana pada titik-titik lokasi tertentu perlu mendapatkan perhatian bagi seluruh pihak untuk dilakukan mitigasi. Hasil lainnya, menunjukkan keselarasan lahan tidak dipengaruhi oleh nilai tanah, karena terlihat pada lahan yang selaras (S) maupun tidak selaras (TS) sama- 
sama pada nilai lahan yang rendah. Dalam perencanaan lahan, aspek ekologi dan ekonomi merupakan aspek penting yang perlu diperhatikan.

Kata kunci: keselarasan, kemampuan lahan, nilai lahan, tata ruang.

\section{PENDAHULUAN}

Kecamatan Ciater terletak pada lokasi yang strategis dan menjadi pintu gerbang Kabupaten Subang menuju ibukota Provinsi Jawa Barat dari arah utara. Seiring berjalannya waktu, wisatawan yang datang ke kawasan wisata Ciater semakin bertambah sehingga daerah ini mengalami perkembangan pesat (BP4D, 2018). Tercatat jumlah kunjungan wisatawan domestik maupun mancanegara di Kabupaten Subang pada urutan 4, setelah Kabupaten Bandung, Bogor dan Karawang, yang di dominan kunjungan ke wilayah Ciater dan sekitarnya (BPS, 2018). Secara ekonomi, hal ini dapat mempengaruhi perkembangan lahan terbangun dan perkembangan nilai tanah disekitarnya (Boavida et al., 2016). Perkembangan ekonomi baik dari sektor pertanian, perdagangan, maupun pariwisata dapat meningkatkan kebutuhan lahan untuk menunjang aktivitas ekonomi pada sektor-sektor tersebut. Semakin tinggi kebutuhan lahan, memicu terjadinya perubahan penggunaan lahan karena lahan sifatnya terbatas, serta dapat berdampak positif maupun negatif terhadap lingkungan (Qu et al., 2018). Terjadinya pertumbuhan penduduk menyebabkan peningkatan kebutuhan lahan di lokasi studi (khususnya sekitar kawasan wisata Ciater), sehingga hal ini dapat memicu terjadinya perubahan penggunaan lahan di kawasan ini.

Daerah Subang bagian selatan memiliki sumberdaya alam yang sangat potensial. Pengelolaan sumberdaya alam, khususnya lahan perlu kebijakan dan strategi publik guna meningkatkan kesejahteraan masyarakat (Ekspodessi et al., 2018; Wang et al., 2018). Setiap penggunaan lahan tertentu memiliki nilai lahan secara ekonomi, sosial, maupun lingkungan (Nakamura, 2019). Pengelolaan sumberdaya alam untuk kepentingan ekonomi terkadang mengabaikan faktor lingkungan. Apabila hal ini tidak dikendalikan maka akan menimbulkan masalah lingkungan. Oleh karena itu, perlu adanya kesinambungan antara penggunaan lahan dengan kebijakan (pola ruang) agar tidak terjadi konflik kepemilikanpenguasaan lahan (Mulya et al., 2019) dan dengan daya dukung lahan (kemampuan lahan), agar tidak terjadi kerusakan atau bencana. Supaya hal negatif tersebut tidak terjadi, maka analisis keselarasan antara penggunaan/pemanfaatan lahan dengan pola ruang (RTRW) perlu dievaluasi (Sitorus et al., 2019) dan juga dengan kemampuan lahannya perlu dilakukan. Tujuan penelitian ini adalah 1). mengetahui jenis tutupan/penggunaan lahan tahun 2006 dan 2019 serta perubahannya, 2). mengevaluasi keselarasan penggunaan lahan 2019 dengan pola ruang RTRW Kabupaten Subang 2011-2031 dan daya dukung lahannya serta informasi zona nilai tanah (ZNT) pada setiap kombinasi keselarasan

\section{BAHAN DAN METODE}

Bahan yang digunakan pada penelitian ini adalah peta penggunaan lahan, Citra Google Earth tahun 2006 dan 2018, peta kemiringan lereng, peta tanah, peta jalan, peta RTRW Kabupaten Subang tahun 2011-2031, dan peta batas administrasi. Peralatan yang digunakan yaitu global positioning system (GPS), kamera smartphone untuk pengamatan lapang, alat tulis dan komputer dengan perangkat lunak berupa software ArcGIS 10.3, google earth pro, avenza maps, microsoft (office dan excel). Jenis data yang digunakan adalah data primer dan data sekunder. Data primer berupa hasil pengecekan lapang jenis penggunaan lahan 2019 dan karakteristik lahan. Data sekunder diperoleh dari instansi dan internet diantaranya citra google earth, peta pola ruang, peta tanah dan peta batas administrasi lokasi studi. Secara rinci data yang digunakan dalam penelitian sesuai disajikan pada Tabel 1.

\section{Tahap Pengamatan Lapang}

Pengamatan lapang dilakukan untuk memperkuat hasil interpretasi citra sekaligus melakukan validasi data, sehingga data yang diperoleh dan telah dianalisis sebelumnya dapat memiliki tingkat akurasi yang tinggi dan sesuai dengan kondisi sebenarnya di lapangan. Pengecekan lapang dilakukan untuk mengetahui penggunaan lahan tahun 2019 di Kecamatan Ciater (berdasarkan citra Tahun 2018). Jika terdapat penggunaan lahan yang tidak sesuai antara hasil pengamatan lapang dan interpretasi citra maka harus dilakukan perbaikan data.

\section{Tahap Analisis Data}

Tahap ini dilakukan setelah semua data yang diperlukan telah terkumpul. Tahapan analisis yang dilakukan terdiri dari:

\section{Analisis Jenis-Jenis Tutupan/Penggunaan Lahan Tahun 2006 dan 2019 serta Perubahan Penggunaan Lahan Tahun 2006-2019}

\section{a) Klasifikasi Tutupan/Penggunaan Lahan}

Klasifikasi tutupan lahan dilakukan pada citra google earth tahun 2006 dan 2018 (diunduh). Kemudian dilakukan koreksi geometri dengan menggunakan software ArcGIS 10.3. Tahap selanjutnya yaitu interpretasi citra secara visual dengan melakukan digitasi tutupan/penggunaan lahan. Digitasi dan interpretasi dilakukan pada skala 1:25,000. Klasifikasi tutupan/penggunaan lahan ini mengacu pada klasifikasi penutup lahan SNI 7645-1:2014 (dimodifikasi) yang diterbitkan oleh Badan Standardisasi Nasional (BSN, 2014). 
Tabel 1 Jenis dan sumber data

\begin{tabular}{|c|c|c|c|c|}
\hline No & $\begin{array}{ll} & \text { Jenis Data } \\
\end{array}$ & Skala & Sumber & Keterangan \\
\hline 1 & Citra google earth Kecamatan Ciater tahun 2006 dan 2018 & - & Google Earth Pro & JPEG File \\
\hline 3 & Peta rencana pola dan struktur ruang RTRW Kabupaten Subang tahun 2011-2031 & 1: 50,000 & BP4D & Shapefile \\
\hline 4 & Peta tanah Kabupaten Subang & 1: 50,000 & BP4D & Shapefile \\
\hline 5 & Peta batas administrasi wilayah Kabupaten Subang & 1: 50,000 & BP4D & Shapefile \\
\hline 6 & Dokumen Kabupaten Subang tahun 2011-2031 & - & BP4D & PDF Document \\
\hline 7 & Dokumen Kabupaten Subang dalam angka 2018 dan Kecamatan Ciater dalam angka 2018 & - & BPS & PDF Document \\
\hline 8 & Peta kemiringan lereng & 1: 25,000 & DEMNAS & Data DEM \\
\hline 9 & Hasil validasi lapang & - & Cek lapang & Data validasi \\
\hline
\end{tabular}

Keterangan: BP4D= Badan Perencanaan Pembangunan Penelitian dan Pengembangan Daerah, DEMNAS= Digital Elevation Model Nasional, BPS $=$ Badan Pusat Statistik.

\section{b) Identifikasi Penggunaan Lahan Tahun 2019}

Pada tahap ini dilakukan pengecekan lapang berdasarkan peta tutupan lahan 2018. Pengecekan lapang dilakukan untuk mengetahui penggunaan lahan saat ini (2019). Penentuan jumlah titik pengamatan dilakukan dengan mempertimbangkan jumlah, sebaran dan luasan poligon masing-masing tutupan/penggunaan lahan serta kemudahan aksesibilitas untuk mencapai tutupan/penggunaan lahan tersebut (purposive sampling). Titik pengamatan tersebut mewakili setiap tutupan/penggunaan lahan sehingga setiap tutupan/penggunaan lahan hasil interpretasi dapat dilakukan validasi data sesuai kondisi di lapangan. Penentuan jumlah sampel dengan menggunakan persamaan slovin (selang kepercayaan 95\%). Apabila terdapat data hasil interpretasi yang tidak sesuai dengan cek lapang maka dilakukan koreksi data mengenai batas, luas dan jenis penggunaan lahan sehingga diperoleh peta penggunaan lahan 2019.

\section{c) Analisis Perubahan Tutupan/ Penggunaan Lahan}

Analisis perubahan tutupan/penggunaan lahan menggunakan peta tutupan/penggunaan lahan tahun 2006 dan 2019. Proses analisis perubahan tutupan/penggunaan lahan dilakukan dengan overlay peta tutupan/penggunaan lahan tahun 2006 dan 2019. Overlay peta dilakukan menggunakan software ArcGIS 10.3 sehingga menghasilkan peta perubahan tutupan/penggunaan lahan Kecamatan Ciater tahun 2006-2019. Analisis perubahan tutupan/penggunaan lahan, menunjukkan berbagai variasi perubahan. Berbagai variasi tersebut dibagi ke dalam dua status yaitu berubah (B) atau tidak berubah (T). Istilah berubah adalah jika keadaan tutupan/penggunaan lahan yang tidak sama di dua titik tahun perbandingan atau lebih dan istilah tidak berubah adalah tutupan/penggunaan lahan yang sama di semua titik tahun perbandingan.

\section{Analisis Kemampuan Lahan}

Menurut Hardjowigeno dan Widiatmaka (2007) dalam tingkat kelas, kemampuan lahan menunjukkan kesamaan dari besarnya faktor-faktor penghambat. Semakin tinggi kelasnya, kualitas lahannya semakin buruk, berarti resiko kerusakan dan besarnya faktor penghambat bertambah dan pilihan penggunaan lahan yang diterapkan semakin terbatas. Awal analisis dimulai dari overlay peta tanah dan peta kelas kemiringan lereng sehingga diperoleh Satuan Peta Lahan (SPL). Dari hasil overlay peta diperoleh 13 SPL. Setelah itu, dilakukan ground check ke lapang untuk mengamati karakterisitik lahan. Pengamatan karakteristik lahan dilakukan pada setiap jenis satuan lahan. Karakteristik lahan yang diamati di lapang meliputi tekstur tanah lapisan atas dan lapisan bawah, drainase, kedalaman efektif, keadaan erosi, banyak batuan dan ancaman banjir. Pengamatan tekstur tanah dilakukan dengan cara lapang, drainase tanah ditentukan dengan mengamati bercak kelabu pada tanah, kedalaman efektif diukur dengan menggunakan bor belgi, keadaan erosi ditentukan dengan mengamati tanda-tanda erosi yang tampak di sekitar lokasi titik pengamatan, banyaknya batuan ditentukan berdasarkan ukuran volume, jumlah dan letak batuan di sekitar titik pengamatan. Peta-peta yang digunakan dalam analisis kemampuan lahan dari berbagai sumber (primer dan sekunder) sesuai disajikan pada Gambar 1. Kriteria kelas kemampuan lahan yang digunakan disajikan pada Tabel 2.

\section{Keselarasan Pengunaan Lahan terhadap Kemampuan Lahan, Pola Ruang dan Informasi Lahan yang Selaras/Tidak Selaras berdasarkan Zona Nilai Tanah (ZNT)}

Pada tahap ini dilakukan overlay secara bersamaan beberapa peta, yaitu peta penggunaan lahan (2019), peta pola ruang RTRW tahun 2011-2031 (Gambar 1), peta kemampuan lahan, peta hasil analisis keselarasan dan peta ZNT. Dalam menentukan keselarasan terlebih dahulu dibuat padanan nomenklatur, khususnya antara penggunaan lahan dengan pola ruang RTRW sesuai disajikan pada Tabel 3. Keselarasan penggunaan lahan dengan berbagai kebijakan dan daya dukung sesuai disajikan dalam matriks keselarasan Tabel 4.

\section{HASIL DAN PEMBAHASAN}

\section{Tutupan/Penggunaan Lahan Kecamatan Ciater Tahun 2006 dan 2019}

Tutupan/penggunaan lahan tahun 2006 terdiri dari 18 tutupan/penggunaan lahan sedangkan tahun 2019 terdapat 19 tutupan/penggunaan lahan. Peta tutupan/penggunaan lahan 2019 diperoleh dari validasi lapang peta tutupan/penggunaan lahan tahun 2018 dengan jumlah pengamatan 74 titik. Sebaran titik lokasi pengamatan dan 19 titik perwakilan setiap jenis penggunaan lahan disajikan pada Gambar 2, sedangkan kenampakan lapang masing-masing penggunaan lahan sesuai disajikan pada Gambar 3. 

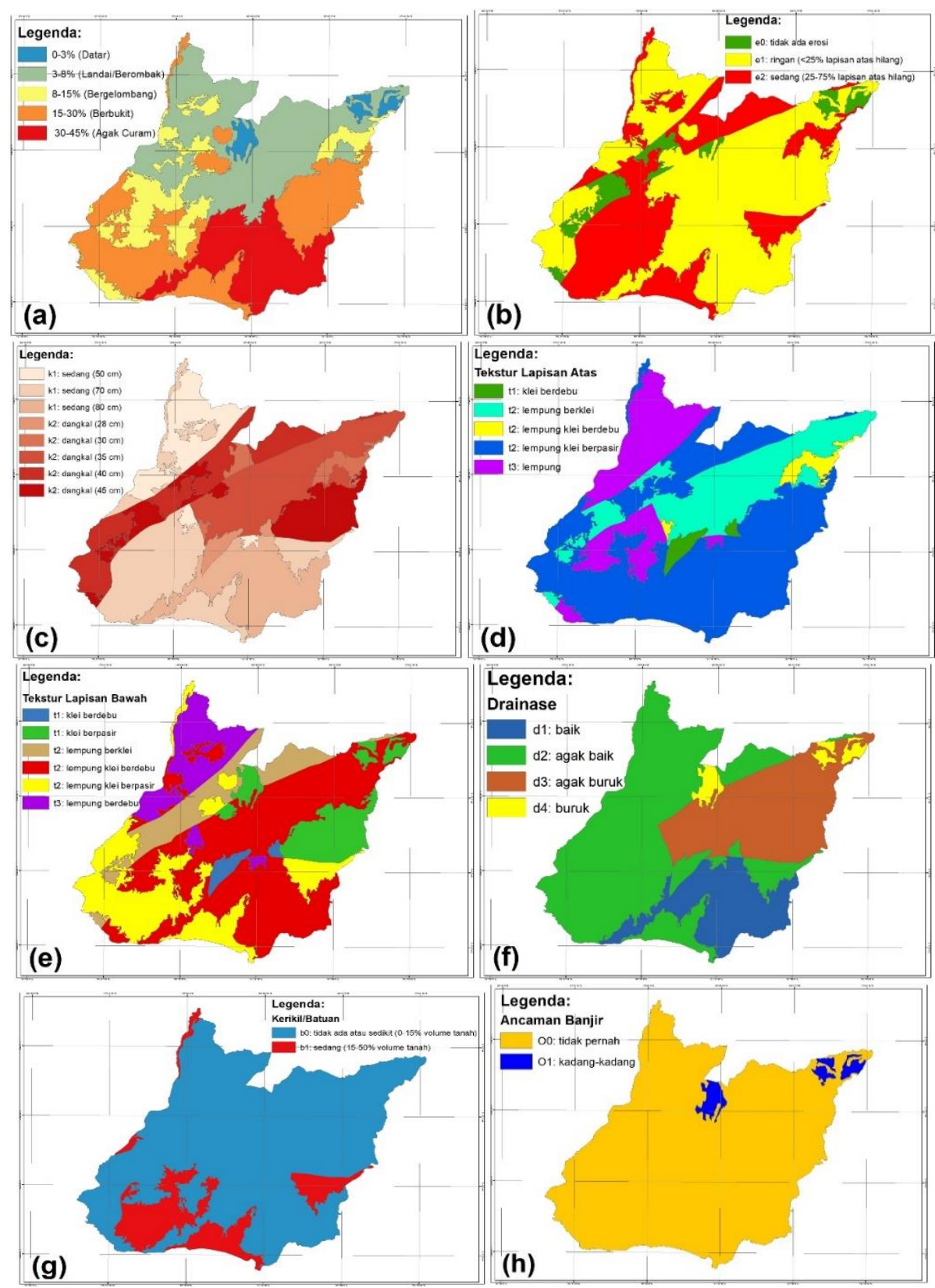

Gambar 1. Peta (a) kelas kemiringan lereng, (b) tingkat erosi, (c) kedalaman efektif, (d) tekstur lapisan atas, (e) tekstur lapisan bawah, (f) drainase, (g) keadaan kerikil/batuan dan (h) ancaman banjir

Tabel 2. Kriteria kelas kemampuan lahan yang digunakan (Arsyad 2010)

\begin{tabular}{|c|c|c|c|c|c|c|c|c|c|}
\hline \multirow{2}{*}{ No } & \multirow{2}{*}{ Faktor } & \multicolumn{8}{|c|}{ Kelas Kemampuan Lahan } \\
\hline & & I & II & III & IV & $\mathbf{V}$ & VI & VII & VIII \\
\hline \multirow{3}{*}{1} & Tekstur tanah (t) & & & & & & & & \\
\hline & a. Lapisan atas $(0-40 \mathrm{~cm})$ & $\mathrm{t} 2 / \mathrm{t} 3$ & $\mathrm{t} 1 / \mathrm{t} 4$ & $\mathrm{t} 1 / \mathrm{t} 4$ & $(*)$ & $(*)$ & $(*)$ & $(*)$ & t5 \\
\hline & b. Lapisan bawah $(>40 \mathrm{~cm})$ & $\mathrm{t} 2 / \mathrm{t} 3$ & $\mathrm{t} 1 / \mathrm{t} 4$ & $\mathrm{t} 1 / \mathrm{t} 4$ & $(*)$ & $(*)$ & $(*)$ & $(*)$ & t5 \\
\hline 2 & Lereng permukaan $(\%)$ & i0 & i1 & i2 & i3 & $(*)$ & $\mathrm{i} 4$ & i5 & i6 \\
\hline 3 & Drainase & $\mathrm{d} 0 / \mathrm{d} 1$ & $\mathrm{~d} 2$ & $\mathrm{~d} 3$ & $\mathrm{~d} 4$ & $(* *)$ & $(*)$ & $(*)$ & $(*)$ \\
\hline 4 & Kedalaman efektif & $\mathrm{k} 0$ & $\mathrm{k} 0$ & k1 & $\mathrm{k} 2$ & $(*)$ & $\mathrm{k} 3$ & $(*)$ & $(*)$ \\
\hline 5 & Keadaan erosi & $\mathrm{e} 0$ & e1 & e1 & e2 & $(*)$ & e3 & $\mathrm{e} 4$ & (*) \\
\hline 6 & Kerikil/batuan & b0 & b0 & b0 & b1 & b2 & $(*)$ & $(*)$ & b2 \\
\hline 7 & Banjir & $\mathrm{O} 0$ & $\mathrm{O} 1$ & $\mathrm{O} 2$ & $\mathrm{O} 3$ & $\mathrm{O} 4$ & (*) & $(*)$ & $(*)$ \\
\hline
\end{tabular}

$(*)=$ dapat mempunyai sembarang sifat faktor penghambat dari kelas yang lebih

$(* *)=$ permukaan tanah selalu tergenang air

Keterangan : $\mathrm{t} 1=$ halus; $\mathrm{t} 2=$ agak halus; $\mathrm{t} 3=$ sedang; $\mathrm{t} 4=$ agak kasar; $\mathrm{t} 5=\mathrm{kasar} \mathrm{k} 0=$ dalam; $\mathrm{k} 1=$ sedang; $\mathrm{k} 2=$ dangkal; $\mathrm{k} 3=\mathrm{sangat}$ dangkal i0 = datar; i1 = landai/berombak; i2 = agak miring/bergelombang; i3 = miring/berbukit; i4 = agak curam; i5 = curam; i6 = sangat curam d0 = baik; $\mathrm{d} 1$ = agak baik; $\mathrm{d} 2$ = agak buruk; $\mathrm{d} 3=$ buruk; $\mathrm{d} 4=$ sangat buruk $\mathrm{e} 0=$ tidak ada erosi; $\mathrm{e} 1$ = ringan; $\mathrm{e} 2=$ sedang; $\mathrm{e}=$ = berat; e4 = sangat berat $\mathrm{b} 0=$ tidak ada atau sedikit; $\mathrm{b} 1=$ sedang; $\mathrm{b} 2=$ banyak; $\mathrm{b} 3=$ sangat banyak $\mathrm{o} 0=$ tidak pernah; $\mathrm{o} 1=$ jarang; $\mathrm{o} 2=\mathrm{kadang}$-kadang; $\mathrm{o} 3=$ sering; $04=$ sangat sering 
Tabel 3. Padanan tutupan/penggunaan lahan dengan pola ruang

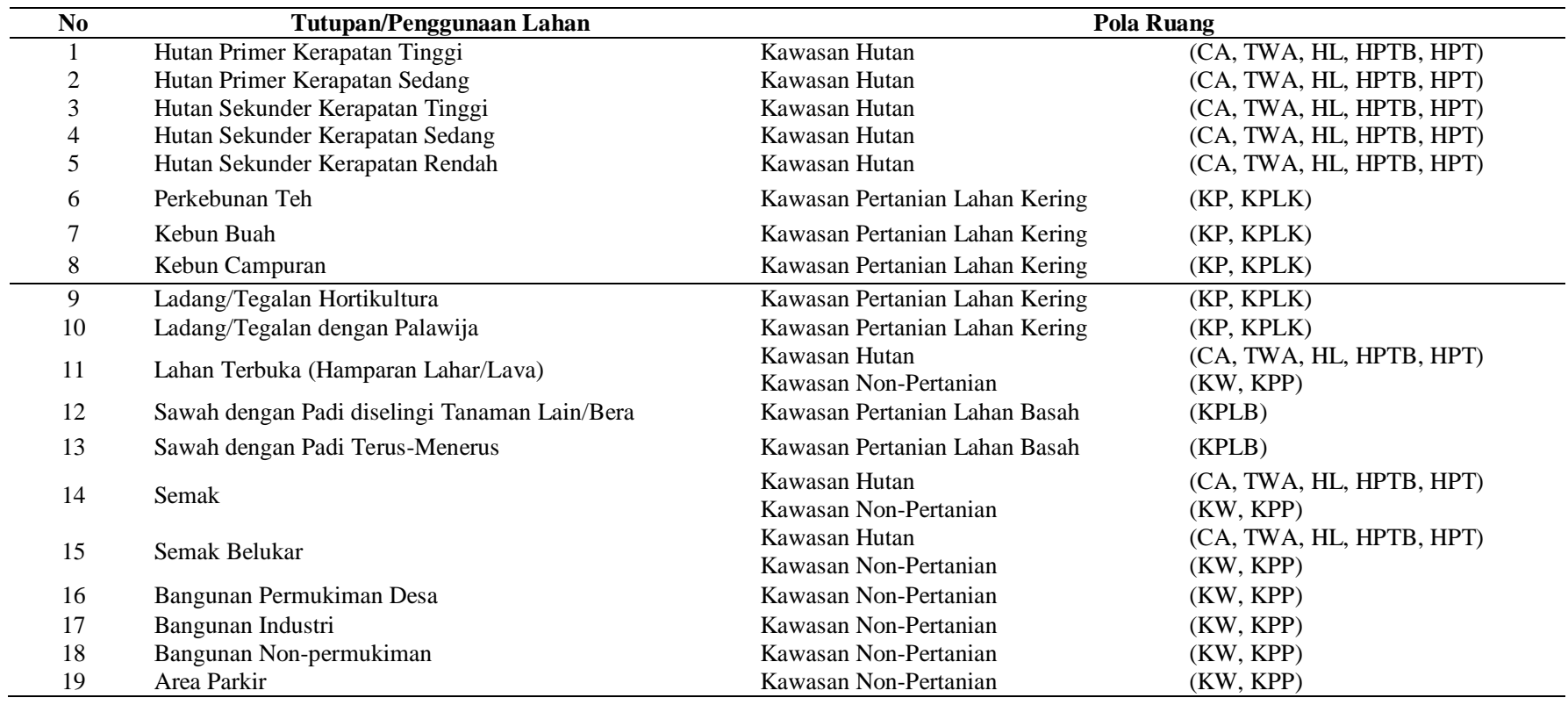

Tabel 4. Matriks keselarasan kemampuan lahan, pola ruang dan penggunaan lahan

\begin{tabular}{|c|c|c|c|c|c|c|}
\hline $\begin{array}{c}\text { Kelas } \\
\text { Kemampuan }\end{array}$ & \multicolumn{2}{|c|}{ Pola Ruang (PR) } & \multicolumn{2}{|c|}{ Penggunaan Lahan (PL) } & $\begin{array}{c}\text { Keselarasa } \\
\text { n (KL, PR, } \\
\text { PL) }\end{array}$ & ZNT \\
\hline \multirow{20}{*}{ II, III, IV } & Kawasan Hutan & (CA, TWA, HL) & Hutan & (HPS, HPT) & \multirow{7}{*}{$\mathrm{S}$} & \multirow{29}{*}{$\begin{array}{c}\text { Rendah/S } \\
\text { edang/Ti } \\
\text { nggi/Tida } \\
\text { k ada } \\
\text { data }\end{array}$} \\
\hline & Kawasan Hutan & (HPTB, HPT) & Hutan & (HSR, HSS, HST) & & \\
\hline & Kawasan Pertanian & $(\mathrm{KP})$ & Lahan Pertanian & $(\mathrm{PT}, \mathrm{KC})$ & & \\
\hline & Kawasan Pertanian & (KPLK) & Lahan Pertanian & (PT, KC, LTH, LTP) & & \\
\hline & Kawasan Pertanian & (KPLB) & Lahan Pertanian & $(\mathrm{SP}, \mathrm{SPB})$ & & \\
\hline & $\begin{array}{l}\text { Kawasan Non- } \\
\text { Pertanian }\end{array}$ & $(\mathrm{KW})$ & Lahan Non-Pertanian & (BNP (Villa)) & & \\
\hline & $\begin{array}{l}\text { Kawasan Non- } \\
\text { Pertanian }\end{array}$ & (KPP) & Lahan Non-Pertanian & (BPD) & & \\
\hline & Kawasan Pertanian & (KP, KPLK, KPLB) & Hutan & (HPS, HPT, HSR, HSS, HST) & & \\
\hline & Kawasan Pertanian & (KPLK) & Lahan Pertanian & $(\mathrm{SP})$ & & \\
\hline & Kawasan Pertanian & (KP, KPLK, KPLB) & Lahan Non-Pertanian & $(\mathrm{S}, \mathrm{SB})$ & $\mathrm{T}$ & \\
\hline & Kawasan Non- & & Hutan & (HPS, HPT, HSR, HSS, HST) & 1 & \\
\hline & Pertanian & $(\mathrm{KW}, \mathrm{KPP})$ & $\begin{array}{l}\text { Lahan Pertanian } \\
\text { Lahan Non-Pertanian }\end{array}$ & $\begin{array}{l}\text { (PT, KB, KC, LTH, LTP, SP, SPB) } \\
\text { (S) (SB) }\end{array}$ & & \\
\hline & Kawasan Hutan & (CA, HL) & Hutan & (HSR, HSS, HST) & & \\
\hline & Kawasan Hutan & (CA, TWA, HL, & Lahan Pertanian & (PT, KC, LTH, LTP, SP, SPB) & & \\
\hline & Kawasan Hutan & (HPTB, HPT) & Lahan Non-Pertanian & (AP, BNP (Villa), BPD, LT) & & \\
\hline & Kawasan Pertanian & $(\mathrm{KP})$ & Lahan Pertanian & (LTH, LTP, SP, SPB) & & \\
\hline & Kawasan Pertanian & (KPLB) & Lahan Pertanian & (PT, KC, LTH, LTP) & & \\
\hline & Kawasan Pertanian & (KP, KPLK, KPLB) & Lahan Non-Pertanian & (AP, BNP (Villa), BPD, LT) & IS & \\
\hline & $\begin{array}{l}\text { Kawasan Non- } \\
\text { Pertanian }\end{array}$ & $(\mathrm{KPP})$ & Lahan Non-Pertanian & $(\mathrm{BNP}(\mathrm{Villa}))$ & & \\
\hline & $\begin{array}{l}\text { Kawasan Non- } \\
\text { Pertanian }\end{array}$ & $(\mathrm{KW})$ & Lahan Non-Pertanian & $(\mathrm{BPD}, \mathrm{BI})$ & & \\
\hline \multirow{9}{*}{ VI } & Kawasan Hutan & (CA, TWA, HL) & Hutan & (HPS, HPT) & \multirow{2}{*}{$\mathrm{S}$} & \\
\hline & Kawasan Hutan & HPTB, HPT) & Hutan & (HSR, HSS, HST) & & \\
\hline & Kawasan Pertanian & (KPLK, KPLB) & Hutan & (HSS) & \multirow[b]{2}{*}{$\mathrm{T}$} & \\
\hline & $\begin{array}{l}\text { Kawasan Non- } \\
\text { Pertanian }\end{array}$ & $(\mathrm{KW})$ & Lahan Pertanian & (LTP) & & \\
\hline & Kawasan Hutan & $(\mathrm{CA}, \mathrm{HL})$ & Hutan & (HSR, HSS, HST) & \multirow{5}{*}{ TS } & \\
\hline & Kawasan Hutan & (CA, TWA, HL, & Lahan Pertanian & (KC, LTH, LTP, SP) & & \\
\hline & Kawasan Hutan & (HPTB, HPT) & Lahan Non-Pertanian & (BPD) & & \\
\hline & Kawasan Pertanian & (KPLK) & Lahan Pertanian & (SP) & & \\
\hline & Kawasan Pertanian & (KPLB) & $\begin{array}{l}\text { Lahan Pertanian } \\
\text { Lahan Non-Pertanian }\end{array}$ & $\begin{array}{l}(\mathrm{KC}, \mathrm{LTP}) \\
(\mathrm{BPD})\end{array}$ & & \\
\hline
\end{tabular}

Keterangan:

- HPS= Hutan Lahan Tinggi Primer Kerapatan Sedang, HPT= Hutan Lahan Tinggi Primer Kerapatan Tinggi, HST= Hutan Lahan Tinggi Sekunder Kerapatan Tinggi, HSS= Hutan Lahan Tinggi Sekunder Kerapatan Sedang, HSR= Hutan Lahan Tinggi Sekunder Kerapatan Rendah, KB= Kebun Buah, KC= Kebun Campuran, LTH= Ladang/Tegalan Hortikultura, LTP= Ladang/Tegalan dengan Palawija, PT= Perkebunan Teh, $\mathrm{SPB}=$ Sawah dengan Padi diselingi Tanaman Lain/Bera, SP= Sawah dengan Padi Terus-menerus, $\mathrm{S}=\mathrm{Semak}, \mathrm{SB}=\mathrm{Semak}$ Belukar, LT= Lahan Terbuka Lain, BPD= Bangunan Permukiman Desa, BNP= Bangunan Non-Permukiman Lain, $\mathrm{AP}=\mathrm{Area}$ Parkir. $\mathrm{CA}=$ 
Cagar Alam, TWA= Taman Wisata Alam, HL= Hutan Lindung, HPTB= Hutan Produksi Terbatas, HPT $=$ Hutan Produksi Tetap, KP= Kawasan Perkebunan, KPLB= Kawasan Pertanian Lahan Basah, KPLK= Kawasan Pertanian Lahan Kering, KW= Kawasan Wisata, KPP= Kawasan Permukiman Perdesaan,

- $\mathrm{S}=$ Selaras, $\mathrm{T}=$ Transisi, $\mathrm{TS}=$ Tidak Selaras.

- ZNT: Nilai Tanah: Rendah= Rp. 16.000-Rp. 237.000, Sedang= Rp. 237.000- Rp. 459.000, Tinggi= Rp. 459.000- Rp. 680.000, Tidak Ada Data $=$ nilai tanah tidak tersedia

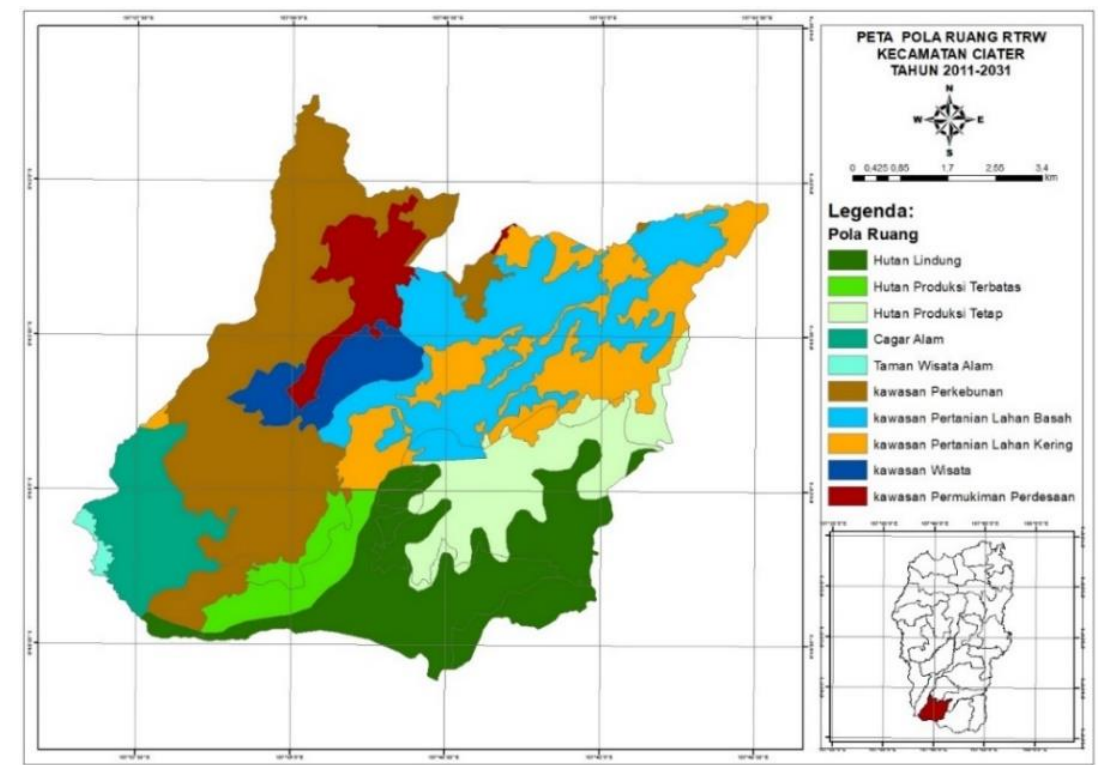

Gambar 1. Peta pola ruang Kecamatan Ciater berdasarkan RTRW Kabupaten Subang 2011-2031

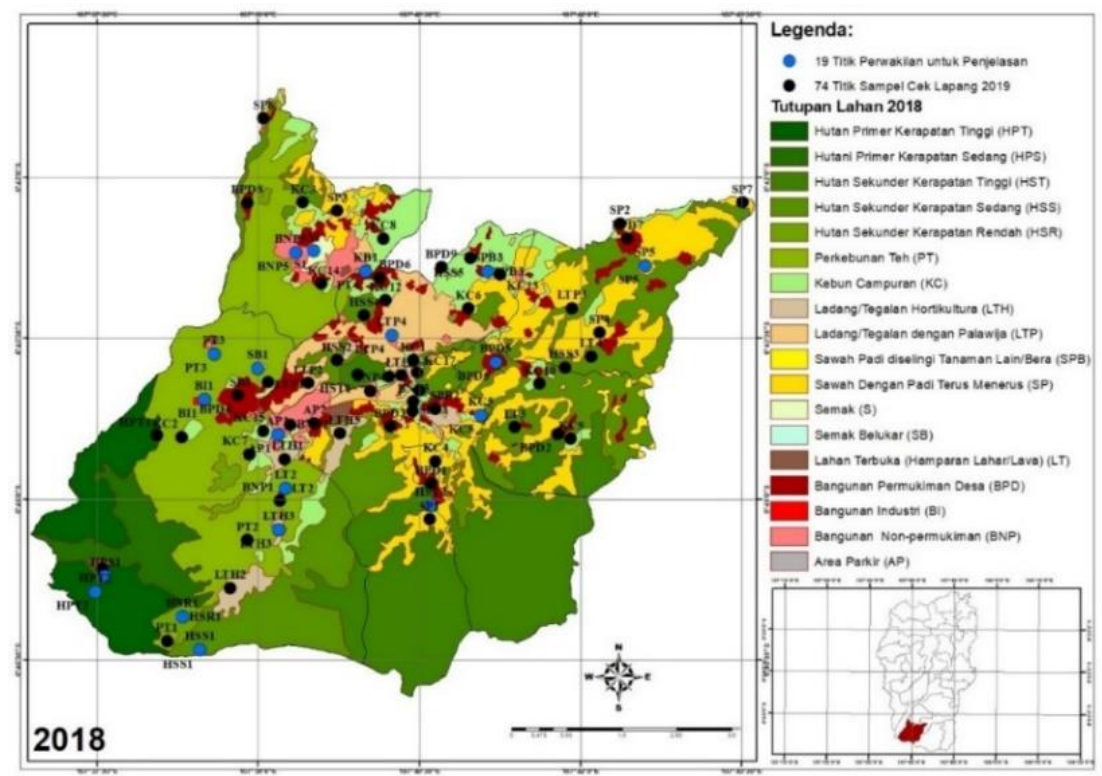

Gambar 2. Peta titik pengamatan di lokasi studi

Tutupan lahan tahun 2006 disajikan pada Gambar 4a, dan tutupan/penggunaan lahan tahun 2019 disajikan pada Gambar 4b. Tiga tutupan/penggunaan lahan terluas pada tahun 2006 adalah hutan sekunder kerapatan sedang, perkebunan teh dan hutan sekunder kerapatan tinggi dengan luas masing-masing $1,510.79$ ha $(22.72 \%), 1,230.88$ ha $(18.51 \%)$ dan $1,180.39$ ha $(17.75 \%)$ Tiga tutupan/penggunaan lahan terluas pada tahun 2019 adalah hutan sekunder kerapatan sedang, hutan sekunder kerapatan tinggi dan perkebunan teh dengan luas masing-masing $1,253.98$ ha $(18.85 \%), 1,183.61$ ha $(17.80 \%)$ dan $1,161.84$ ha $(17.47 \%)$. Tutupan/penggunaan lahan yang memiliki luasan paling kecil pada tahun 2006 adalah semak belukar dengan luas 2.34 ha $(0.04 \%)$, bangunan industri dengan luas 2.52 ha $(0.04 \%)$ dan area parkir dengan luas 4.03 ha $(0.06 \%)$. Tutupan/penggunaan lahan yang memiliki luasan paling kecil pada tahun 2019 adalah semak belukar dengan luas 2.34 ha $(0.04 \%)$, bangunan industri dengan luas 2.52 ha $(0.04 \%)$ dan kebun buah dengan luas 2.7 ha $(0.04 \%)$.

Hal ini menunjukkan bahwa di Kecamatan Ciater masih banyak lahan hutan sebagai daerah resapan air dan kawasan lindung bagi daerah di bawahnya. Kelestarian hutan harus dijaga agar tidak terjadi alih fungsi lahan terhadap kawasan hutan. Informasi mengenai luasan dan persentase luasan 
tutupan/penggunaan lahan tahun 2006 dan 2019 disajikan pada Tabel 5.

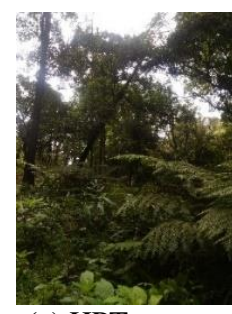

(a) HPT

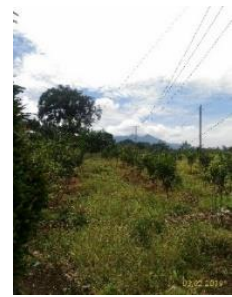

(f) $\mathrm{KB}$

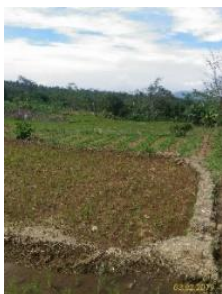

(k) SPB

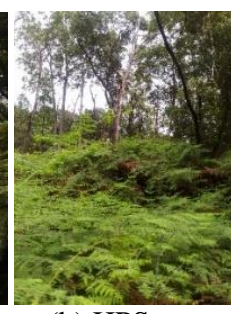

(b) HPS

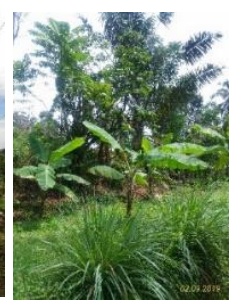

(g) KC

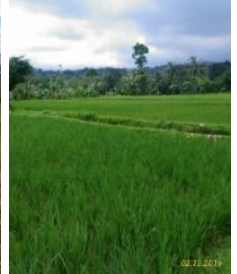

(1) SP

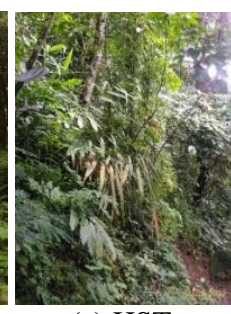

(c) HST

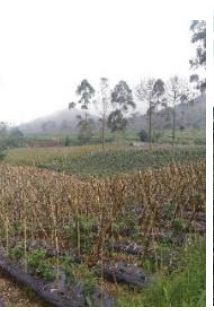

(h) LTH

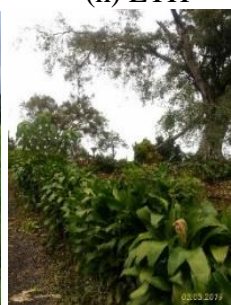

(m) SB

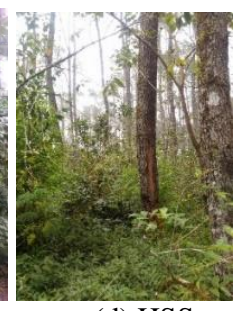

(d) HSS

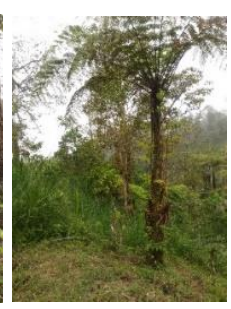

(e) HSR

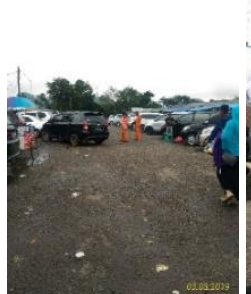

(p) $\mathrm{AP}$

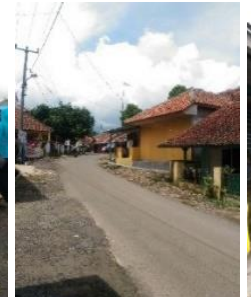

(q) BPD

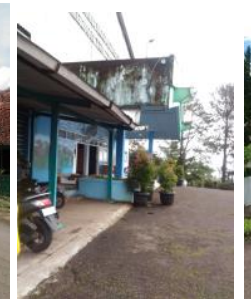

(r) BI

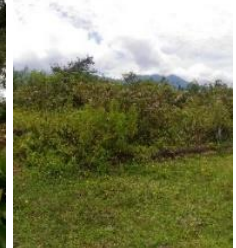

(n) $\mathrm{S}$

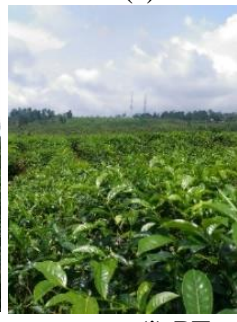

(j) PT

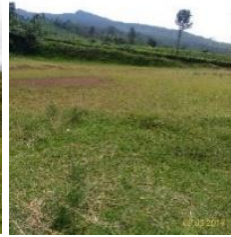

(o) LT

Keterangan: (a) hutan primer kerapatan tinggi (HPT), (b) hutan primer kerapatan sedang (HPS), (c) hutan sekunder kerapatan tinggi (HST), (d) hutan sekunder kerapatan sedang (HSS), (e) hutan sekunder kerapatan rendah (HSR), (f) kebun buah, (g) kebun campuran (KC), (h) ladang/tegalan hortikultura (LTH), (i) ladang/tegalan dengan palawija (LTP), (j) perkebunan teh (PT), (k) sawah dengan padi diselingi tanaman lain/bera (SPB), (1) sawah dengan padi terus-menerus (SP), (m) semak belukar (SB), (n) semak (S), (o) lahan terbuka (hamparan lahar/lava) (LT), (p) area parkir (AP), (q) bangunan permukiman desa (BPD), (r) bangunan industri (BI) dan (s) bangunan non-permukiman (BNP)

Gambar 3. Pengamatan lapang penggunaan lahan tahun 2019 di Kecamatan Ciater
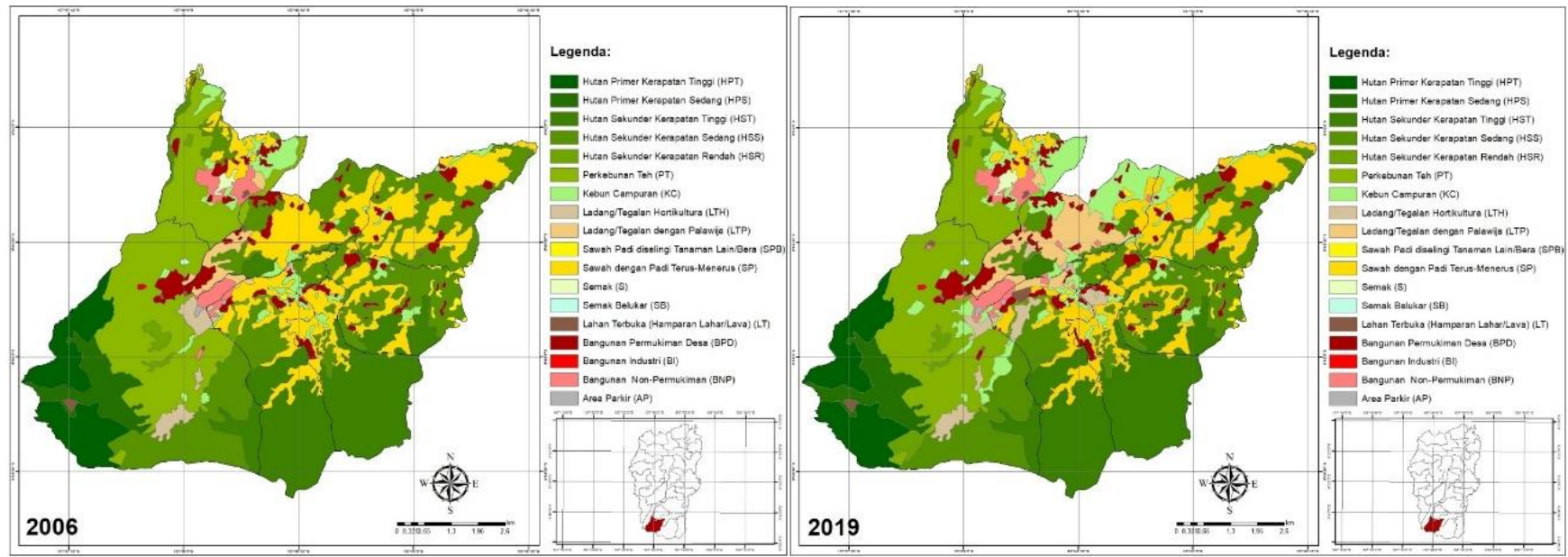

Gambar 4. Peta tutupan/penggunaan lahan tahun (a). 2006 dan (b). 2019 


\section{Perubahan Tutupan/Penggunaan Lahan Kecamatan Ciater Tahun 2006-2019}

Analisis perubahan tutupan/penggunaan lahan dilakukan pada dua titik tahun yaitu tahun 2006 dan 2019. Pada tahun 2006 - 2019 terdapat 36 kombinasi perubahan penggunaan lahan (Gambar 5). Perubahan tutupan/penggunaan lahan 10 (sepuluh) terbesar sesuai disajikan pada Gambar 6. Sementara itu, informasi perubahan tutupan/penggunaan lahan 3 (tiga) terbesar adalah dari penggunaan lahan sawah (padi sepanjang tahun) menjadi ladang/tegalan dengan palawija sebanyak 189.54 ha, perubahan dari hutan sekunder kerapatan sedang menjadi kebun campuran dengan luas 104.44 ha dan perubahan tutupan lahan dari perkebunan teh menjadi kebun campuran dengan luas 64.95 ha. Perkembangan suatu wilayah akan berdampak pada meningkatnya tekanan terhadap lahan dan perubahan penggunaan lahan sebagai akibat peningkatan jumlah penduduk, aktivitas sosial, dan aktivitas ekonomi masyarakat (Sitorus, 2017).

Pada rentang waktu 2006 hingga 2019 di Kecamatan Ciater banyak terjadi konversi lahan pada penggunaan lahan hutan, perkebunan dan sawah. Pada lahan hutan dan perkebunan teh sering terjadi pembukaan lahan tanpa izin oleh sebagian masyarakat. Konversi lahan hutan banyak terjadi pada hutan sekunder kerapatan sedang, baik itu berubah kerapatannya menjadi kerapatan rendah karena penebangan ataupun berubah menjadi penggunaan lain seperti kebun campuran, ladang/tegalan dan sebagainya karena aktivitas manusia yang melakukan pembukaan lahan hutan. Pada lahan sawah banyak mengalami perubahan menjadi ladang/tegalan maupun lahan terbangun seperti permukiman dan villa. Selain itu, pada lahan sawah banyak terjadi alih komoditas dari tanaman padi menjadi tanaman hortikultura, palawija maupun tanaman buah-buahan.

Perubahan tutupan/penggunaan lahan paling luas terjadi di Desa Palasari. Menurut warga banyaknya lahan persawahan yang berubah menjadi ladang/tegalan maupun kebun campuran terjadi karena produktivitas padi dari tahun ke tahun semakin menurun akibat gangguan hama dan kesuburan tanah semakin yang menurun. Pada awalnya petani mengubah sistem pertanaman padi dari setahun 3 kali menjadi 2 kali atau bahkan sekali dalam setahun dan diselingi dengan ladang/tegalan atau dibiarkan begitu saja. Seiring berjalannya waktu para petani mulai tertarik dengan berladang karena menganggap berladang lebih menguntungkan dari pada menanam padi. Hal ini menyebabkan sebagian besar petani padi berhenti menanam padi dan beralih ke komoditas lain seperti ladang/tegalan palawija dan hortikultura, kebun campuran dan sebagainya.

Perubahan yang terjadi dikarenakan minat menanam pada suatu komoditas yang sering berubah-ubah. Dengan semakin menurunnya hasil yang diperoleh dari menanam padi, masyarakat mulai beralih untuk menanam komoditas lain yang dianggap lebih menguntungkan seperti sayur-sayuran dan sebagainya. Selain itu, bercocok tanam lahan kering seperti ladang, tegalan dan kebun campuran akan lebih sedikit membutuhkan air sehingga pada saat persediaan air terbatas petani tidak harus susah mencari air karena kebutuhan air pertanian lahan kering tidak sebanyak pertanian padi sawah.

Pada penggunaan lahan ladang/tegalan palawija, petani di Kecamatan Ciater biasanya menanam singkong, kacang tanah, ubi jalar dan jagung sedangkan pada ladang/tegalan hortikultura biasa ditanami dengan sayursayuran, seperti cabai, mentimun, kacang panjang, tomat dan sebagainya. Pada kebun campuran biasanya ditanami pohon tahunan seperti pohon sengon, manggis, alpukat, cengkih dan sebagainya yang dipadukan dengan tanaman nanas, pisang dan tanaman lainnya. Pohon-pohon tahunan tersebut juga biasanya dikombinasikan dengan tanaman semusim baik berupa tanaman palawija maupun tanaman hortikultura. Selain berubah penggunaannya, lahan-lahan juga banyak dijual oleh para petani karena mendapat penawaran dengan harga tinggi.

Tabel 5. Luas tutupan/penggunaan lahan Kecamatan Ciater tahun 2006 dan 2019

\begin{tabular}{|c|c|c|c|c|c|}
\hline \multirow{2}{*}{ No. } & \multirow{2}{*}{$\begin{array}{c}\text { Tutupan/ } \\
\text { Penggunaan Lahan }\end{array}$} & \multicolumn{2}{|c|}{ Tahun 2006} & \multicolumn{2}{|c|}{ Tahun 2019} \\
\hline & & Luas (ha) & Proporsi $(\%)$ & Luas (ha) & Proporsi (\%) \\
\hline 1 & Hutan Primer Kerapatan Tinggi (HPT) & 433.49 & 6.52 & 433.49 & 6.52 \\
\hline 2 & Hutan Primer Kerapatan Sedang (HPS) & 223.52 & 3.36 & 223.52 & 3.36 \\
\hline 3 & Hutan Sekunder Kerapatan Tinggi (HST) & $1,180.39$ & 17.75 & $1,183.61$ & 17.80 \\
\hline 4 & Hutan Sekunder Kerapatan Sedang (HSS) & $1,510.79$ & 22.72 & $1,253.98$ & 18.85 \\
\hline 5 & Hutan Sekunder Kerapatan Rendah (HSR) & 68.48 & 1.03 & 88.04 & 1.32 \\
\hline 6 & Kebun Buah (KB) & 0.00 & 0.00 & 2.70 & 0.04 \\
\hline 7 & Kebun Campuran (KC) & 235.73 & 3.54 & 527.03 & 7.92 \\
\hline 8 & Ladang/Tegalan Hortikultura (LTH) & 94.73 & 1.42 & 131.14 & 1.97 \\
\hline 9 & Ladang/Tegalan dengan Palawija (LTP) & 82.49 & 1.24 & 270.54 & 4.07 \\
\hline 10 & Lahan Terbuka (Hamparan Lahar/Lava) (LT) & 16.08 & 0.24 & 28.11 & 0.42 \\
\hline 11 & Perkebunan Teh $(\mathrm{PT})$ & $1,230.88$ & 18.51 & $1,161.84$ & 17.47 \\
\hline 12 & Sawah dengan Padi diselingi tanaman lain/Bera (SPB) & 33.10 & 0.50 & 38.70 & 0.58 \\
\hline 13 & Sawah dengan Padi Terus-menerus (SP) & $1,141.62$ & 17.17 & 852.73 & 12.82 \\
\hline 14 & Semak $(S)$ & 13.88 & 0.21 & 17.59 & 0.26 \\
\hline 15 & Semak Belukar (SB) & 2.34 & 0.04 & 2.34 & 0.04 \\
\hline 16 & Bangunan Permukiman Desa (BPD) & 269.47 & 4.05 & 298.48 & 4.49 \\
\hline 17 & Bangunan Industri (BI) & 2.52 & 0.04 & 2.52 & 0.04 \\
\hline 18 & Bangunan Non-permukiman (BNP) & 107.14 & 1.61 & 130.28 & 1.96 \\
\hline 19 & Area Parkir (AP) & 4.03 & 0.06 & 4.03 & 0.06 \\
\hline & Jumlah & $6,650.67$ & 100.00 & $6,650.67$ & 100.00 \\
\hline
\end{tabular}



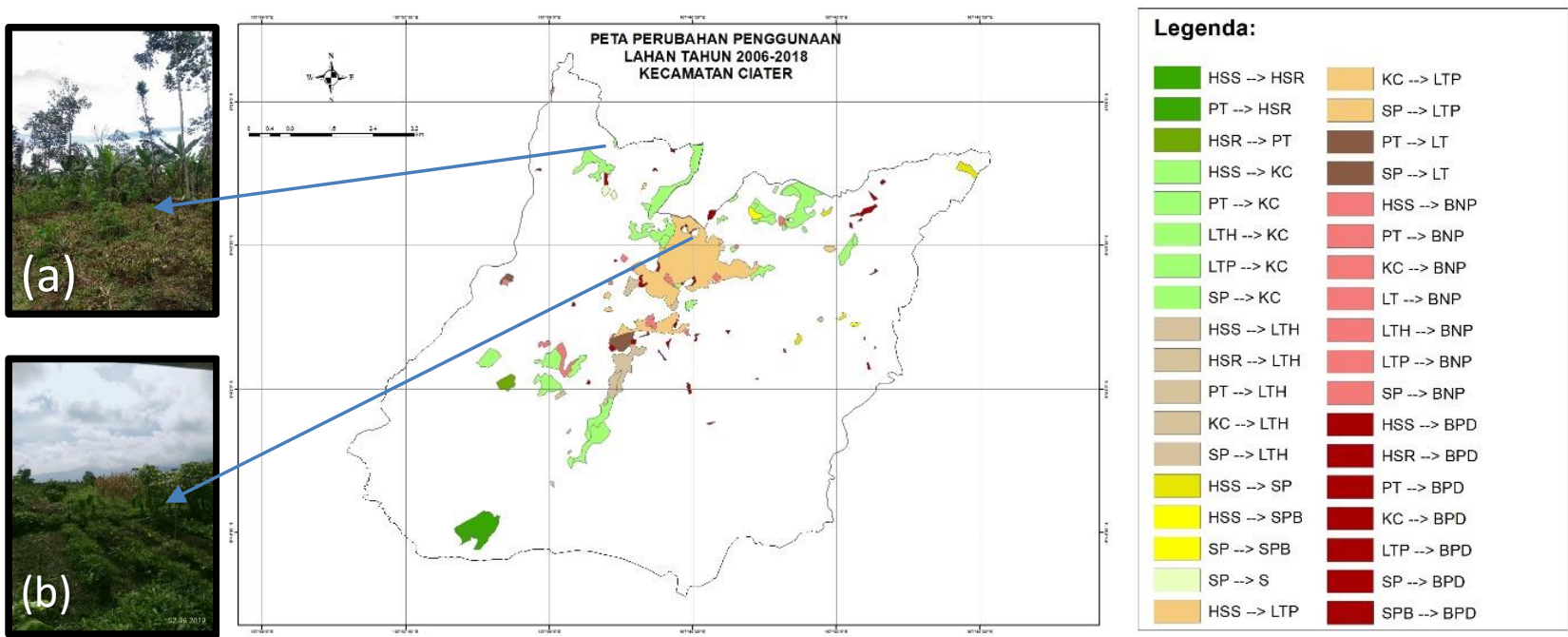

Keterangan:

- HSS = Hutan Lahan Tinggi Sekunder Kerapatan Sedang, HSR= Hutan Lahan Tinggi Sekunder Kerapatan Rendah, KC= Kebun Campuran, LTH= Ladang/Tegalan Hortikultura, LTP= Ladang/Tegalan dengan Palawija, PT= Perkebunan Teh, SPB= Sawah dengan Padi diselingi Tanaman Lain/Bera, SP= Sawah dengan Padi Terus-menerus, S=Semak, LT= Lahan Terbuka Lain, BPD= Bangunan Pemukiman Desa, $\mathrm{BNP}=$ Bangunan Non-pemukiman Lain.

- (a). hutan sekunder kerapatan sedang menjadi kebun campuran (Desa Cisaat) dan (b) sawah dengan padi terus-menerus menjadi ladang/tegalan dengan palawija (Desa Palasari)

Gambar 5. Peta perubahan tutupan/penggunaan lahan tahun 2006-2019 dan kenampakan di lapangan lahan yang berubah saat ini

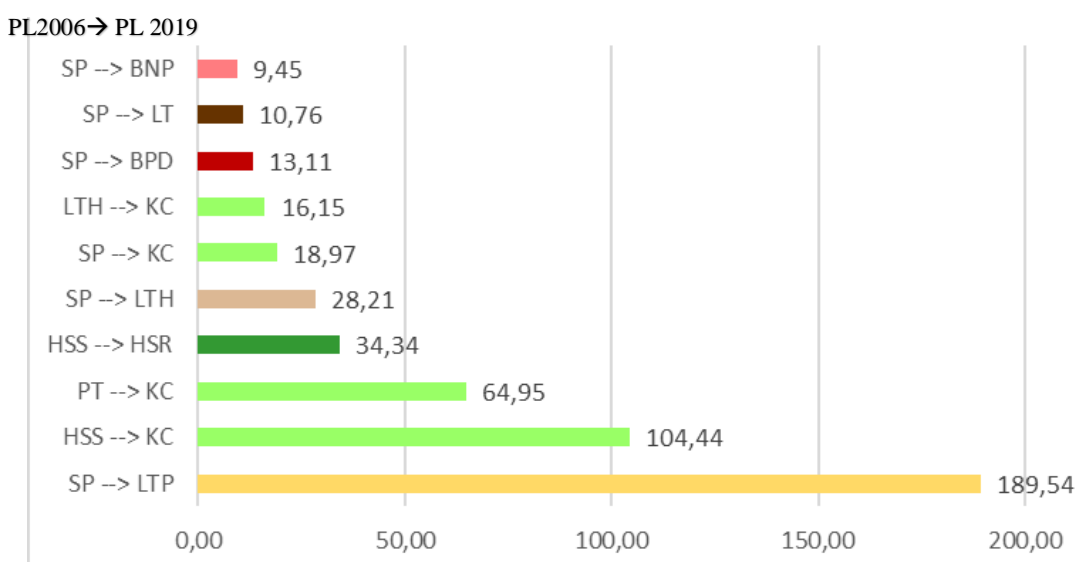

Gambar 6. Grafik 10 perubahan terbesar tutupan lahan tahun 2006-2019; PL = tutupan/penggunaan lahan

\section{Perubahan Tutupan Lahan berdasarkan Pola Ruang RTRW Kabupaten Subang tahun 2011-2031}

Pola ruang yang terdapat di Kecamatan Ciater terdiri dari 10 kawasan pola ruang. Dari 10 kawasan tersebut disederhanakan menjadi 3 kawasan, yaitu Kawasan Hutan, Kawasan Pertanian dan Kawasan Non-Pertanian (Tabel 3). Perubahan penggunaan lahan antara tahun 20062019 yang paling luas terjadi pada Kawasan Pertanian, yaitu pada Kawasan Perkebunan, Kawasan Pertanian Lahan Basah dan Kawasan Pertanian Lahan Kering sebesar 446.07 Ha atau $78.56 \%$ dari total luas perubahan penggunaan lahan di Kecamatan Ciater, sedangkan pada Kawasan NonPertanian (Kawasan Wisata dan Kawasan Permukiman Perdesaan) sebesar $81.48 \mathrm{Ha}(14.35 \%)$ dan pada Kawasan Hutan (Hutan Produksi Terbatas dan Hutan Produksi Tetap) sebesar $40.27 \mathrm{Ha}$ (7.09\%). Distribusi spasial perubahan tutupan lahan berdasarkan pola ruang sesuai disajikan pada Gambar 7.

\section{Kemampuan Lahan}

Kelas kemampuan lahan memiliki tingkat kesamaan faktor-faktor pembatas dengan 8 (delapan) kelas kemampuan lahan yang dikelompokkan ke dalam kelas I sampai dengan kelas VIII. Dalam kaitannya dengan penggunaan lahan, semakin tinggi kelas kemampuan lahannya maka semakin sedikit pilihan penggunaan lahannya, dimana pertimbangan kualitas lahan yang semakin buruk dan memiliki faktor pembatas yang besar. Semakin rendah kelas kemampuan lahannya maka kualitas lahannya semakin baik dan memiliki faktor pembatas yang kecil, sehingga sesuai untuk banyak penggunaan lahan (Lynn et al., 2009). 


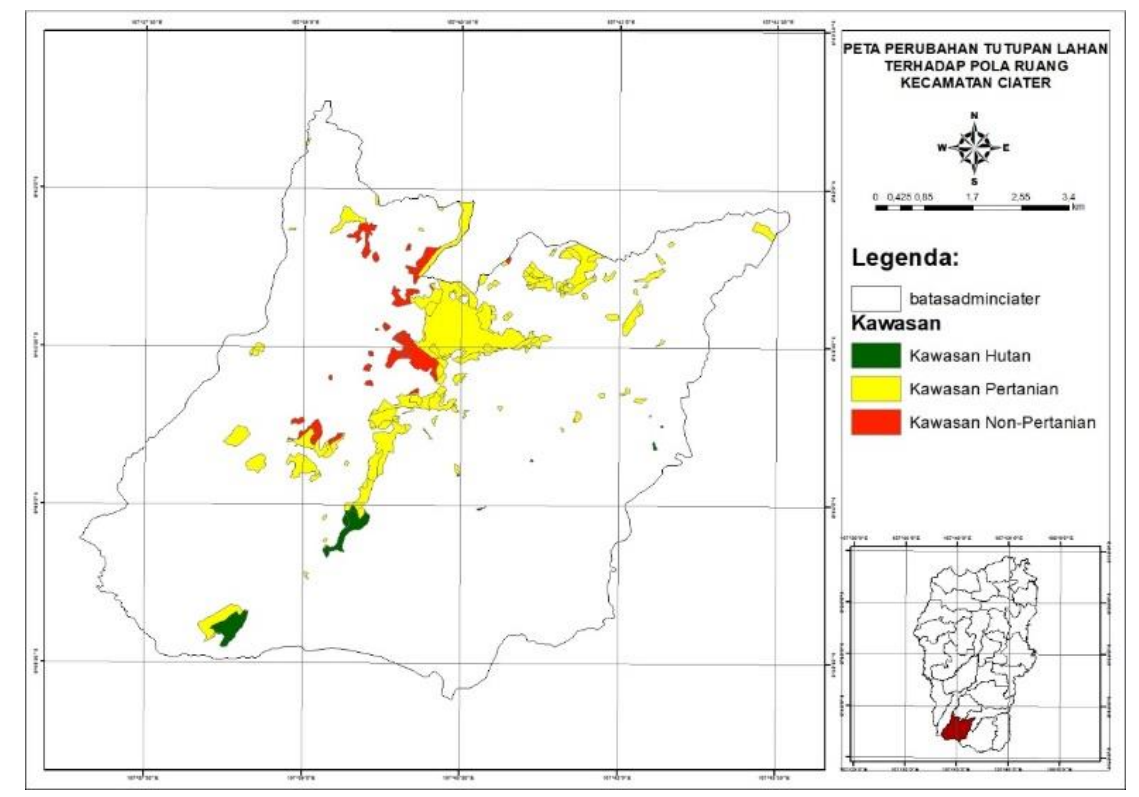

Gambar 7. Peta perubahan tutupan lahan terhadap pola ruang

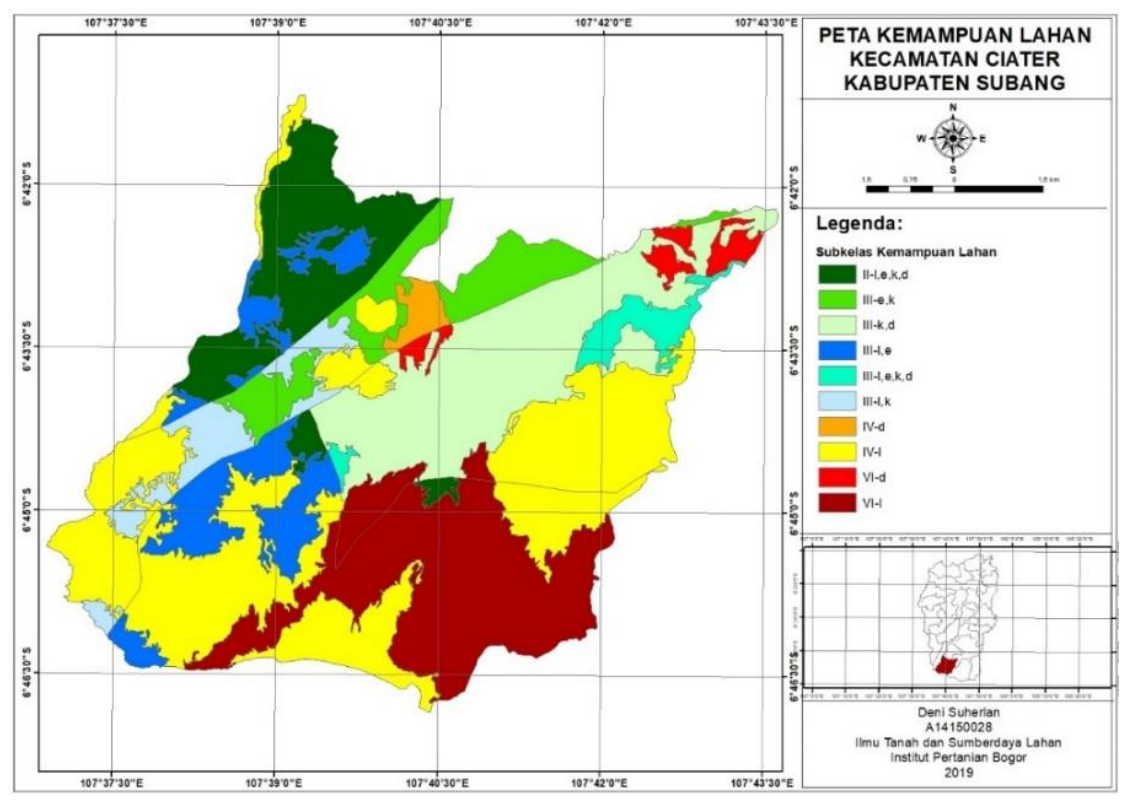

Gambar 8. Peta kemampuan lahan Kecamatan Ciater

Tabel 6. Luas kelas kemampuan lahan Kecamatan Ciater

\begin{tabular}{|c|c|c|c|c|c|c|c|c|c|}
\hline \multirow[t]{2}{*}{ No } & \multirow{2}{*}{\multicolumn{2}{|c|}{$\begin{array}{c}\text { Kelas Kemampuan } \\
\text { Lahan }\end{array}$}} & \multirow{2}{*}{$\begin{array}{c}\text { Subkelas } \\
\text { Kemampuan } \\
\text { Lahan }\end{array}$} & \multicolumn{2}{|c|}{$\begin{array}{c}\text { Luas Subkelas } \\
\text { Kemampuan Lahan }\end{array}$} & \multicolumn{2}{|c|}{$\begin{array}{c}\text { Luas Kelas Kemampuan } \\
\text { Lahan }\end{array}$} & \multicolumn{2}{|c|}{$\begin{array}{c}\text { Luas Kelas } \\
\text { (II, III, IV) } \\
\text { dan VI }\end{array}$} \\
\hline & & & & ha & $\%$ & ha & $\%$ & ha & $\%$ \\
\hline \multirow{8}{*}{1} & \multirow{8}{*}{ II, III, IV } & II & II-l,e,k,d & 706.42 & 10.62 & 706.42 & 10.62 & \multirow{8}{*}{$5,312.43$} & \multirow{8}{*}{79.89} \\
\hline & & & III-e,k & 454.28 & 6.83 & & & & \\
\hline & & & III-k,d & $1,117.89$ & 16.81 & & & & \\
\hline & & III & III-1,e & 538.04 & 8.09 & $2,532.86$ & 38.09 & & \\
\hline & & & III-1,e,k,d & 157.52 & 2.37 & & & & \\
\hline & & & III-1,k & 265.14 & 3.99 & & & & \\
\hline & & IV & IV-d & 69.99 & 1.05 & $2,073.15$ & 31.18 & & \\
\hline & & IV & IV-1 & $2,003.15$ & 30.12 & $2,073.15$ & 31.18 & & \\
\hline \multirow[t]{2}{*}{2} & \multirow[t]{2}{*}{ VI } & VI & $\begin{array}{l}\text { VI-d } \\
\text { VI-1 }\end{array}$ & $\begin{array}{r}123.29 \\
1,213.81\end{array}$ & $\begin{array}{r}1.85 \\
18.25\end{array}$ & $1,337.11$ & 20.11 & $1,337.11$ & 20.11 \\
\hline & & umlah & & $6,649.54$ & 100.00 & $6,649.54$ & 100.00 & $6,649.54$ & 100.00 \\
\hline
\end{tabular}


Dalam analisis yang dilakukan di daerah penelitian terdapat 4 (empat) kelas kemampuan lahan antara lain kelas II, III, IV dan VI yang tersebar di seluruh wilayah Kecamatan Ciater. Kelas kemampuan lahan terluas adalah lahan kelas III, yaitu 2,532.86 ha atau $38.09 \%$ dari total luas lokasi studi. Kelas kemampuan lahan II merupakan kelas dengan luasan terendah yaitu 706.42 ha $(10.62 \%)$. Terdapat 1 sub kelas kemampuan lahan untuk kelas II, 5 sub kelas untuk kelas III, 2 sub kelas untuk kelas IV dan 2 sub kelas untuk kelas VI (Gambar 8). Luas masing-masing kelas kemampuan lahan disajikan pada Tabel 6.

Faktor pembatas dari kelas II dan III adalah lereng, erosi, kedalaman efektif dan drainase sedangkan pada kelas IV dan VI adalah lereng dan drainase. Sub kelas kemampuan lahan dengan luasan terbesar adalah sub kelas IV dengan faktor pembatas lereng (IV-l) sebesar 2,003.15 ha atau $30.12 \%$ dari total luas Kecamatan Ciater sedangkan sub kelas IV dengan faktor pembatas drainase (IV-d) merupakan sub kelas dengan luasan terendah yaitu sebesar 69.99 ha (1.05\%). Kelas kemampuan lahan II, III dan IV di Kecamatan Ciater seluas 5,312.43 ha (79.89\%), sedangkan kelas kemampuan lahan VI seluas $1,337.11$ ha $(20.11 \%)$. Hal ini mengindikasikan bahwa $79.89 \%$ lahan di Kecamatan Ciater dapat dimanfaatkan sebagai kawasan budidaya baik itu lahan hutan produksi, lahan pertanian maupun lahan non-pertanian.

\section{Keselarasan Penggunaan Lahan terhadap Kemampuan Lahan, Pola Ruang dan Informasi Lahan yang Selaras/Tidak Selaras berdasarkan Zona Nilai Tanah (ZNT)}

Analisis keselarasan ditentukan berdasarkan matriks keselarasan yang disajikan pada Tabel 4. Hasil analisis menunjukkan selaras seluas $3,807.15$ ha $(57.25 \%)$, $1,359.36$ ha $(20.44 \%)$ tidak selaras, sedangkan $1,483.02$ ha (22.30\%) merupakan transisi. Data selengkapnya sesuai disajikan pada Tabel 7 dan sebaran spasial masing-masing keselarasan disajikan pada Gambar 9.

Tabel 7. Keselarasan Penggunaan Lahan terhadap Kemampuan Lahan, Pola Ruang

\begin{tabular}{clcr}
\hline \multirow{2}{*}{ No } & \multirow{2}{*}{ Keselarasan } & ha & Luas \\
\cline { 3 - 4 } & & $3,807.2$ & 57.3 \\
1 & Selaras & $1,483.0$ & 22.3 \\
2 & Transisi & $1,358.4$ & 20.4 \\
3 & Tidak Selaras & $6,648.5$ & 100.0 \\
\hline
\end{tabular}

Apabila diuraikan, contoh penggunaan lahan yang tidak selaras dengan pola ruang salah satunya terdapat di Desa Cibitung (Gambar 10a). Di Desa Cibitung terdapat Kampung Sukasari yang secara pola ruang berada pada kawasan hutan produksi tetap (HPT). Kampung tersebut terletak jauh dari pusat pemerintahan Kecamatan Ciater dan berada di lereng pegunungan. Jika dilihat dari aspek kebijakan maka penggunaan lahan berupa permukiman yang terletak di kawasan HPT merupakan suatu pelanggaran terhadap pola ruang yang ada. Namun demikian, pola ruang yang disusun terkadang tidak mempertimbangkan keadaan di lapang dan potensi lahan. Pada kasus seperti ini salah satu upaya yang dapat dilakukan adalah dengan revisi rencana pola ruang agar menyesuaikan dengan kondisi eksisting yaitu berupa permukiman perdesaan dan mempertimbangkan aspek lingkungan. Sementara itu, penggunaan lahan yang tidak selaras dengan kemampuan lahan salah satunya terdapat di Desa Ciater (Gambar 10b) pada penggunaan lahan ladang/tegalan hortikultura yang berada pada kelas kemampuan lahan VI. Hal ini selaras dengan hasil penelitian Fahmi et al. (2016), ketidakselarasan pemanfaatan ruang (dengan kebijakan/daya dukung) disebabkan oleh beberapa hal, yaitu; (1) kekeliruan dalam penyusunan RTRW yang tidak mempertimbangkan faktor daya dukung dan daya tampung lahan, terkait kesesuaian dan kelayakan lahannya; (2) meningkatnya laju pertumbuhan ekonomi yang diikuti dengan pertambahan jumlah penduduk sehingga memacu terjadinya peningkatan intensitas pemanfaatan lahan; (3) adanya investasi atau penanaman modal sehingga Pemerintah Daerah yang memegang kekuasaan otonominya memberikan izin penggunaan lahan di luar koridor kawasan yang telah ditetapkan dalam rencana pola ruang yang telah disepakati.

Selanjutnya, informasi lahan yang selaras/tidak selaras dioverlay dengan peta ZNT guna mengetahui potensi lahan secara ekonomi berdasarkan kondisi keselarasannya. Hasil analisis menunjukkan lahan yang selaras (S) dan tidak selaras (TS) (antara PL, KL, dan PR) dengan nilai tanah rendah memiliki luasan berturut-turut paling besar dibandingkan kombinasi lainnya yaitu seluas 2,427.41 Ha (36.50\%) dan 1,122.94 ha (16.89\%) (Tabel 8). Ini menunjukkan bahwa di wilayah studi keselarasan tidak terlalu berpengaruh terhadap nilai tanahnya. Terlihat dari baik lahan yang selaras maupun tidak selaras didominasi pada ZNT rendah. Distribusi spasial keselarasan berdasarkan informasi ZNT sesuai disajikan pada Gambar 11 dan Tabel 8 


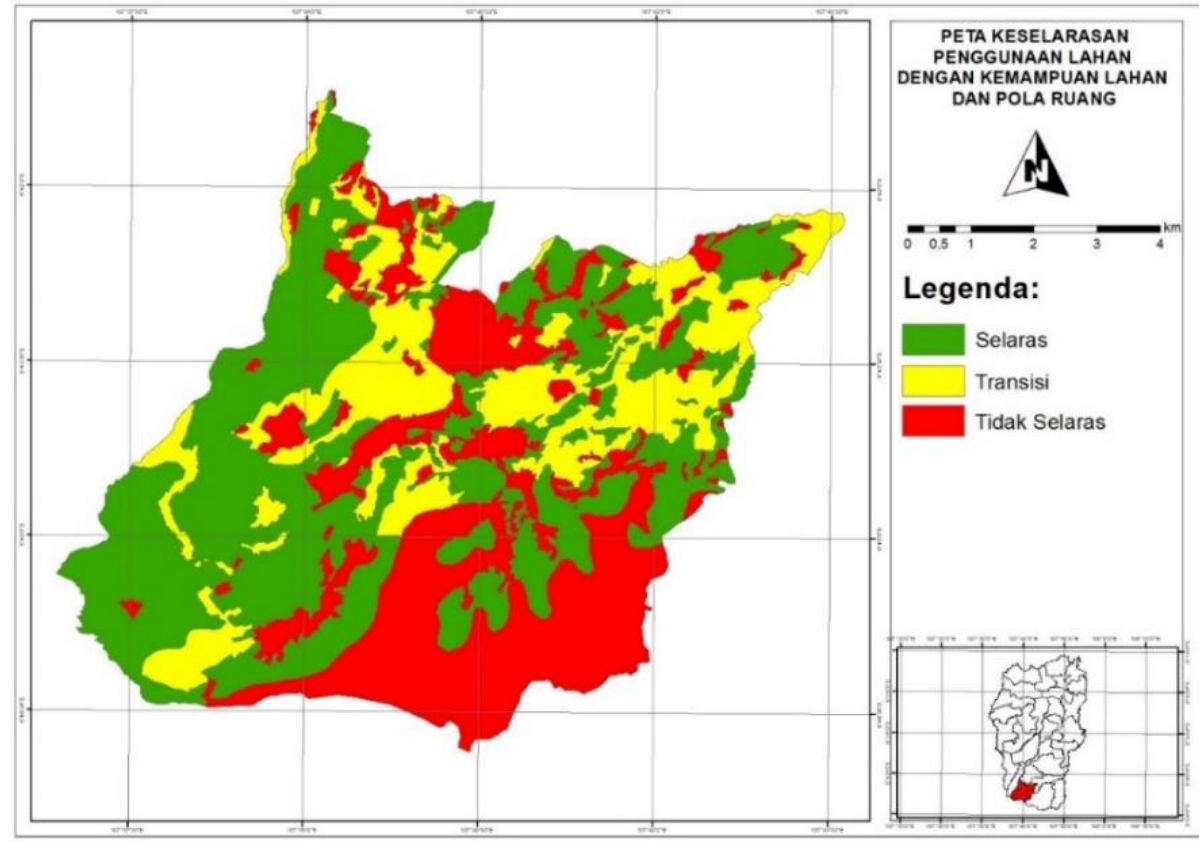

Gambar 9. Peta keselarasan penggunaan lahan dengan kemampuan lahan dan pola ruang Kecamatan Ciater

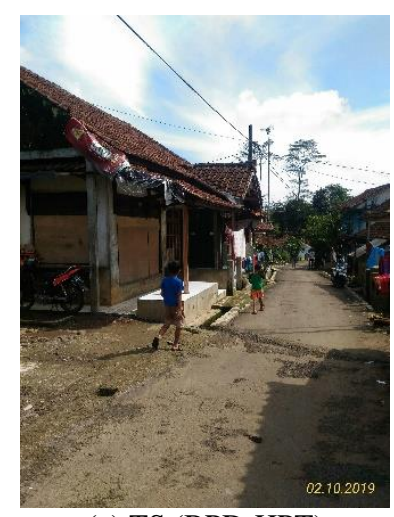

(a) TS (BPD-HPT)

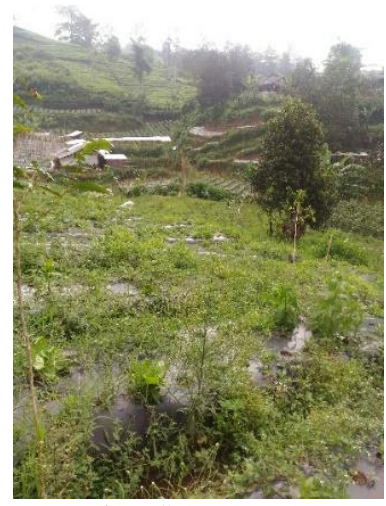

(b) TS (LTH-VI)

Keterangan: TS=Tidak Selaras, BPD= Bangunan Permukiman Perdesaan, HPT= Hutan Produksi Tetap, LTH= Ladang/Tegalan Hortikultura, VI=kelas kemampuan lahan VI.

Gambar 10. Pengamatan lapang lokasi yang tidak selaras antara: a) penggunaan lahan dengan pola ruang dan b). penggunaan lahan dengan kelas kemampuan lahan

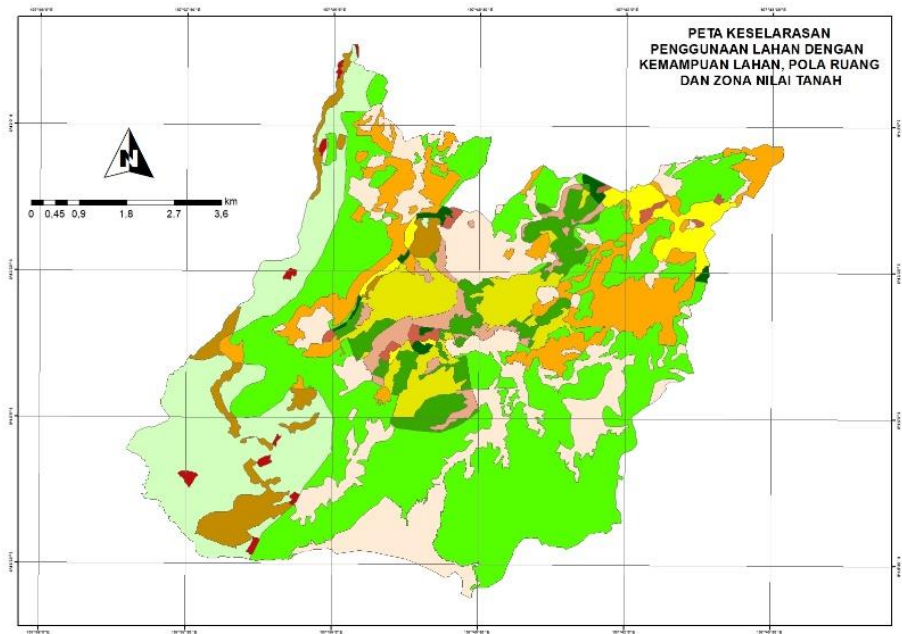

\section{Legenda:}

\begin{tabular}{|l|l}
\hline S-ZNT (Tinggi) \\
S-ZNT (Sedang) \\
S-ZNT (Rendah) \\
S-ZNT (Tidak Ada Data) \\
\hline T-ZNT (Tinggi) \\
\hline T-ZNT (Sedang) \\
\hline T-ZNT (Rendah) \\
T-ZNT (Tidak Ada Data) \\
\hline TS-ZNT (Rendah) \\
\hline TS-ZNT (Sedang) \\
\hline TS-ZNT (Tinggi) \\
\hline TS-ZNT (Tidak Ada Data)
\end{tabular}

Keterangan: $\quad \mathrm{S}=$ Selaras, $\mathrm{T}=$ Transisi, TS=Tidak Selaras. Nilai Tanah: Rendah=Rp. 16.000-Rp. 237.000, Sedang=Rp. 237.000- Rp. 459.000, Tinggi= Rp. 459.000- Rp. 680.000, Tidak Ada Data= nilai tanah tidak tersedia

Gambar 11. Peta informasi lahan selaras/tidak selaras berdasarkan zona nilai tanah 
Tabel 8. Luasan keselarasan penggunaan lahan dengan kemampuan lahan, pola ruang dan zona nilai tanah

\begin{tabular}{|c|c|c|c|c|}
\hline Informasi Keselarasan dilihat dari ZNT & $\begin{array}{c}\text { Luas } \\
\text { (ha) }\end{array}$ & Proporsi (\%) & $\begin{array}{l}\text { Luas } \\
\text { (ha) }\end{array}$ & $\begin{array}{l}\text { Proporsi } \\
(\%)\end{array}$ \\
\hline S-ZNT Rendah & $2,427.41$ & 36.50 & $3,807.15$ & 57.25 \\
\hline S-ZNT Sedang & 318.45 & 4.79 & & \\
\hline S-ZNT Tinggi & 43.91 & 0.66 & & \\
\hline S-Tidak Ada Data & $1,017.39$ & 15.30 & & \\
\hline T-ZNT Rendah & 684.38 & 10.29 & $1,483.02$ & 22.30 \\
\hline T-ZNT Sedang & 379.10 & 5.70 & & \\
\hline T-ZNT Tinggi & 158.88 & 2.39 & & \\
\hline T-Tidak Ada Data & 260.66 & 3.92 & & \\
\hline TS-ZNT Rendah & $1,122.94$ & 16.89 & $1,359.36$ & 20.44 \\
\hline TS-ZNT Sedang & 162.57 & 2.44 & & \\
\hline TS-ZNT Tinggi & 44.58 & 0.67 & & \\
\hline TS-Tidak Ada Data & 29.27 & 0.44 & & \\
\hline Jumlah & $6,649.54$ & 100.00 & $6,649.54$ & 100.00 \\
\hline
\end{tabular}

\section{SIMPULAN}

Tutupan/penggunaan lahan terluas adalah hutan sekunder kerapatan sedang dengan persentase $22.72 \%$ (tahun 2006), dan 18.85\% (tahun 2019). Perubahan yang paling luas adalah dari hutan sekunder kerapatan sedang pada tahun 2006 berubah menjadi kebun campuran pada tahun 2019 dengan luas 173.35 ha (25.25\%). Pola umum perubahan tutupan/penggunaan lahan pada umumnya dari lahan hutan menjadi lahan pertanian kemudian menjadi lahan terbangun.

Berdasarkan kemampuan lahannya lahan seluas 79.89\% di Kecamatan Ciater dapat dimanfaatkan sebagai kawasan budidaya baik itu lahan hutan produksi, lahan pertanian maupun lahan nonpertanian (kelas I-IV). Dilihat dari keselarasannya $57.25 \%$ selaras dengan PR-KL-PL, 20.44\% tidak selaras dan $22.30 \%$ transisi. Secara umum, keselarasan lahan tidak dipengaruhi oleh nilai tanah, karena terlihat pada lahan yang selaras $(\mathrm{S})$ maupun tidak selaras (TS) sama-sama pada nilai lahan yang rendah.

Dalam perencanaan lahan, pertimbangan terhadap aspek ekologi, ekonomi dan sosial penting untuk dilakukan agar dapat berkelanjutan. Kebijakan (pola ruang) yang baik harus mempertimbangkan aspek-aspek tersebut. Dengan demikian, perencanaan lahan juga harus sesuai dengan kebijakan yang ada.

\section{DAFTAR PUSTAKA}

Arsyad, S. 2010. Konservasi Tanah dan Air. IPB Press. Bogor

[BPS] Badan Pusat Statistik Provinsi Jawa Barat. 2018. Kunjungan wisatawan ke Obyek Wisata Menurut Kabupaten/Kota di Jawa Barat. BPS Provinsi Jawa Barat, Bandung.

[BSN] Badan Standardisasi Nasional. 2014. Standar Nasional Indonesia (SNI) Klasifikasi Penutupan Lahan-Bagian I Skala Kecil dan Menengah. Badan Standardisasi Nasional, Jakarta.

[BAPPEDA] Badan Perencanaan Pembangunan Penelitian dan Pengembangan Daerah. 2018. Rancangan Awal Rencana Pembangunan Jangka Menengah Daerah (RPJMD) Kabupaten Subang Tahun 20182023. Subang
Boavida, I, J. Rocha and C.C. Ferreira. 2016. Exploring the impact of future tourism development on land use/cover changes. Applied Geography, 77: 82-91. https://doi.org/10.1016/j.apgeog.2016.10.009

Ekpodessi, S.G.N. and H. Nakamura. 2018. Land use and management in Benin Republic: An evaluation of the effectiveness of Land Law 2013-01. Land Use Policy, 78: 61-69. https://doi.org/10.1016/j.landusepol.2018.06.025.

Fahmi, F., S.R.P. Sitorus, dan A. Fauzi. 2016. Evaluasi pemanfaatan penggunaan lahan berbasis rencana pola ruang Kota Baubau, Provinsi Sulawesi Tenggara. J. Tata Loka, 18(1): 27-39.

Hardjowigeno, S. dan Widiatmaka. 2007. Evaluasi Kesesuaian Lahan dan Perencanaan Tataguna Lahan. Gadjah Mada University Press, Yogyakarta.

Lynn, I.H., A.K. Manderson, M.J. Page, G.R. Harmsworth, G.O. Eyles, G.B. Douglas, A.D. Mackay and P.J.F. Newsome. 2009. Land Use Capability Survey Handbook - a New Zealand handbook for the Classification of Land 3rd ed. Hamilton, AgResearch: Lincoln, Landcare Research: Lower Hutt, GNS Science. New Zealand

Mulya, S.P., E. Rustiadi, W.F. Chan dan A.E. Pravitasari. 2019. Perubahan Tutupan Lahan dan Keselarasan dengan Kebijakan Ruang di Sub DAS Ciliwung Hulu. Prosiding Seminar Nasional Asosiasi Sekolah Perencanaan Indonesia (ASPI) 2019. hal 104-114.E-ISBN 978-623-91612-0-0

Nakamura, H. 2019. Relationship among land price, entrepreneurship, the environment, economics, and social factors in the value assessment of Japanese cities. J. of Cleaner Production, 217:144152. https://doi.org/10.1016/j.jclepro.2019.01.201

[PEMDA] Pemerintah Daerah Kabupaten Subang. 2014. Peraturan Daerah Kabupaten Subang Nomor 3 Tahun 2014 tentang Rencana Tata Ruang Wilayah Kabupaten Subang Tahun 2011-2031. Pemerintah Daerah Kabupaten Subang, Subang.

Qu, Y. and H. Long. 2018. The Economic and environmental effect of land use transitions under 
rapid urbanization and the implications for land use management. Habitat International, 82: 113121.

https://doi.org/10.1016/j.habitatint.2018.10.009

Sitorus, S.R.P. 2017. Perencanaan Penggunaan Lahan. IPB Press, Bogor.

Sitorus, S.R.P, E. Mustamei dan S.P. Mulya. 2019. Keselarasan penggunaan lahan dengan pola ruang dan arahan pengembangan ruang terbuka hijau di Kabupaten Bengkulu Selatan. J. Ilmu Tanah dan
Lingkungan, $21(1):$
https://doi.org/10.29244/jit1.21.1.21-29

Wang, J., T. He and Y. Lin. 2018. Changes in ecological, agricultural, and urban land space in 1984-2012 in China: Land policies and regional socialeconomical drivers. Habitat International, 71: 113.

https://doi.org/10.1016/j.habitatint.2017.10.010 